\title{
SLK wt Allele
}

National Cancer Institute

\section{Source}

National Cancer Institute. SLK wt Allele. NCI Thesaurus. Code C131220.

Human SLK wild-type allele is located in the vicinity of $10 \mathrm{q} 25.1$ and is approximately $62 \mathrm{~kb}$ in length. This allele, which encodes STE20-like serine/threonine-protein kinase protein, plays a role in both apoptosis and protein phosphorylation. 